\title{
PENGEMBANGAN BAHAN AJAR BERBASIS AUDIO VISUAL TERHADAP HASIL BELAJAR SISWA PADA MATERI POKOK BANGUN RUANG KUBUS DAN BALOK KELAS VIII DI SMP N 1 CILEDUG
}

\author{
Megan Antropa Legendari, Hendri Raharjo \\ Tadris Matematika, IAIN Syekh Nurjati Cirebon \\ Jalan perjuangan Bypass Sunyaragi
}

\begin{abstract}
As an educator, a teacher must be able to implement and create a conducive learning atmosphere and fun during the learning process takes place so that students can be motivated to learn the spirit . This study aims to : (1) Develop non-print instructional materials in the form of audio- visual based teaching materials for students of class VIII SMP Negeri 1 Ciledug , (2) To determine the students' response to mathematics learning through audio-visual -based teaching materials. The method used in the development of mathematics teaching materials are the kind of research and development ADDIE models. Some stages will be carried out in the research and development are: (1) analysis, ( 2 ) design, ( 3 ) development, (4) implementation, and ( 5 ) evaluation. This research resulted in a product such as the development of audio-visual -based teaching materials that have been validated by experts in their field. Furthermore, the results of product testing, to see the effectiveness test which concluded that based on the calculation of Two Independent Sample Test results obtained value $Z \_$hitung $>Z \_$tabel (-3.917 > -1.96) and Asym. Sig ( 2 - tailed ) of $0.000<$ 0.05 , thus it can be concluded there is a difference in learning outcomes between the experimental class and the class of the $N$-gain control, this can be seen in the experimental class rank 50.65 and control class rank of 30,35 , thus it can be concluded that the experimental class learning outcomes better than the control class.
\end{abstract}

Keywords: Development of Teaching Materials, Audio-visual.

\section{PENDAHULUAN}

Keberhasilan seorang guru dalam pembelajaran sangatlah diharapkan, untuk mengetahui tujuan tersebut diperlukan suatu persiapan yang matang. Sebelum guru mengajar (tahap persiapan) seorang guru diharapkan mempersiapkan bahan yang mau diajarkan, mempersiapkan alat-alat peraga/praktikum yang akan digunakan, mempersiapkan pertanyaan dan arahan untuk memancing siswa aktif belajar, mempelajari keadaan siswa, mengerti kelemahan dan kelebihan siswa, serta mempelajari pengetahuan awal siswa, kesemuanya ini akan terurai pelaksanaannya didalam perangkat pembelajaran.

Proses belajar mengajar merupakan kegiatan interaksi antara guru-siswa dan komunikasi timbal balik yang berlangsung dalam situasi edukatif untuk mencapai tujuan belajar. Interaksi dan komunikasi timbal balik antara guru-siswa merupakan ciri dan syarat utama bagi berlangsungnya proses belajar mengajar.

Melalui proses komunikasi, pesan/informasi dapat diserap dan dihayati orang lain. Agar tidak terjadi kesesatan dalam proses komunikasi perlu digunakan sarana yang membantu proses komunikasi yang disebut media. Dalam proses belajar mengajar, media yang digunakan untuk memperlancar komunikasi belajar mengajar disebut media pembelajaran.

Pembelajaran berbasis komputer sangat efektif dan menjadi alternatif yang penting dalam pendidikan. Banyak pengajar mulai tertarik untuk melibatkan komputer sebagai sarana belajar. Komputer sebagai 
salah satu produk teknologi mutakhir yang serba bisa dapat digunakan sebagai media pembelajaran untuk mengajarkan materimateri matematika, terutama materi-materi matematika yang memerlukan penjelasan grafik dan gambar sekaligus, dimana hal itu dimungkinkan dengan menggunakan media komputer sebagai media pandang dengar atau audio visual. Program-program komputer dengan segala kelebihannya dapat digunakan oleh seorang guru untuk menciptakan suatu pembelajaran yang baik dan dirancang semenarik mungkin.

National Education Association (1969) mengungkapkan bahwa media pembelajaran adalah sarana komunikasi dalam bentuk cetak maupun pandang dengar, termasuk teknologi perangkat keras (Baskoro, 2008 : 1). Bentuk cetak disini bisa berupa bahan ajar, bahan ajar merupakan salah satu media yang dapat dimanfaatkan dalam proses pembelajaran baik itu bahan ajar cetak maupun non cetak.

Berdasarkan studi pendahuluan di SMP N 1 Ciledug, wawancara dengan guru bidang studi matematika pada tanggal 1 April 2014, yaitu Ibu Waryuni, S.Pd. mengungkapkan bahwa sebagian besar siswa menganggap matematika sebagai materi yang sangat sulit bagi mereka. Sehingga penguasaan siswa terhadap materi pelajaran matematika masih tergolong rendah, salah satunya pada materi bangun ruang kubus dan balok. Ketika proses pembelajaran berlangsung, menggunakan bantuan berupa media microsoft powerpoint, sebagian siswa masih belum bisa memahami materi yang tercantum dalam slide dengan alasan kurang menarik siswa itu sendiri dan materinya kurang lengkap.

Dengan pemanfaatan perkembangan teknologi saat ini, peneliti mencoba mengembangkan bahan ajar berbasis audio visual yang didesain semenarik mungkin, bahan ajar ini bisa dipelajari oleh siswa dimana saja, kapan saja dan tidak ada batasan waktu untuk dipelajari. Sehingga akan tercipta proses belajar mengajar yang efektif dan efisien, serta menyenangkan. Pada akhirnya dapat meningkatkan hasil belajar matematika siswa.

\section{KAJIAN TEORI}

Kata media merupakan bentuk jamak dari medium yang secara harfiah tengah, pengantar, atau perantara. Dalam bahasa Arab media adalah perantara atau pengantar pesan dari pengirim pesan. (Arsyad, $2003: 3)$.

Association for Education and Communication Technology (AECT) mendefinisikan media yaitu segala bentuk yang dipergunakan untuk suatu proses penyaluran informasi. Sedangkan National Education Association (NEA) mendefinisikan media sebagai benda yang dapat dimanipulasikan, dilihat, didengar, dibaca atau dibicarakan beserta instrumen yang dipergunakan dengan baik dalam kegiatan belajar mengajar, dapat mempengaruhi efektifitas program instruktional. (Asnawir, 2002 : 11).

Pembelajaran dapat diartikan sebagai proses kerjasama antara guru dan siswa dalam memanfaatkan segala potensi dan sumber yang ada baik potensi yang bersumber dari dalam diri siswa itu sendiri seperti minat, bakat dan kemampuan dasar 
yang dimiliki termasuk gaya belajar maupun potensi yang ada diluar diri siswa seperti lingkungan, sarana dan sumber sebagai upaya untuk mencapai tujuan belajar tertentu. (Sanjaya, 2009 : 26).

Multimedia adalah media yang menggabungkan dua unsur atau lebih media yang terdiri dari teks, grafik, gambar, foto, audio, dan animasi secara terintegrasi. (Istiyanto.com/pengertian-dan-manfaat-

multimedia-pembelajaran/)

Multimedia terbagi menjadi dua kategori, yaitu multimedia linier dan multimedia interaktif. Multimedia linier adalah suatu multimedia yang tidak dilengkapi dengan alat pengontrol apapun yang dapat dioperasikan oleh pengguna. Adapun multimedia interaktif adalah multimedia yang dilengkapi dengan alat pengontrol yang dapat dioperasikan oleh pengguna sehingga pengguna dapat memilih apa yang dikehendaki untuk proses selanjutnya. (Hamdani, 2011 : 191). Pembelajaran merupakan suatu kegiatan yang melibatkan seseorang dalam upaya memperoleh pengetahuan, keterampilan dan nilai-nilai positif dengan memanfaatkan berbagai sumber untuk belajar. (Susilawan, 2011 : 1).

Bahan ajar adalah segala bentuk bahan atau materi yang disusun secara sistematis yang digunakan untuk membantu guru atau instruktur dalam melaksanakan kegiatan belajar mengajar sehingga tercipta lingkungan atau suasana yang memungkinkan siswa untuk belajar. (Hamdani, 2011 : 120). Menurut Andi Prastowo ( 2011 : 28) bahan ajar merupakan sebuah susunan atas bahan-bahan yang berhasil dikumpulkan dan berhasil dari berbagai sumber belajar yang dibuat secara sistematis. Sedangkan menurut Sofan dan Lif ( 2010 : 159) mengatakan bahwa bahan ajar adalah segala bentuk bahan yang digunakan untuk membantu guru/instruktur dalam melaksanakan kegiatan belajar mengajar dikelas.

Manfaat Bahan Ajar

Manfaat bahan ajar terbagi menjadi dua, yaitu :

1) Manfaat Bagi Guru

a) Diperoleh bahan ajar yang sesuai tuntutan kurikulum dan sesuai dengan kebutuhan belajar peserta didik.

b) Tidak lagi tergantung kepada buku teks yang terkadang sulit untuk diperoleh.

c) Memperkaya karena dikembangkan dengan menggunakan berbagai referensi.

d) Menambah khasanah pengetahuan dan pengalaman guru dalam menulis bahan ajar.

e) Membangun komunikasi pembelajaran yang efektif antara guru dengan peserta didik karena peserta didik akan merasa lebih percaya kepada gurunya.

f) Menambah angka kredit jika dikumpulkan menjadi buku diterbitkan. (Sofan, 2010 : 159)

2) Manfaat Bagi Peserta Didik Menurut Sofan dan Ali (2010 : 160) bahan ajar sangat banyak manfaatnya bagi peserta didik oleh karena itu harus disusun secara bagus, manfaatnya seperti dibawah ini :

a) Kegiatan pembelajaran menjadi lebih menarik. 
b) Kesempatan untuk belajar secara mandiri dan mengurangi ketergantungan terhadap kehadiran guru.

c) Mendapatkan kemudahan dalam mempelajari setiap kompetensi yang harus dikuasainya. (Sofan, 2010 : 160)

Asnawir dan Utsman (2002 : 57) mengemukakan, media visual dua dimensi merupakan media yang bersifat elektronik yang diproyeksikan dan terdiri dari perangkat keras (hardware) dan perangkat lunak (software). Penggunaan media ini memerlukan aliran listrik untuk dapat menggerakkan pemakainya. Ada beberapa jenis media visual dua dimensi ini, antara lain 1) Overhead Proyektor, 2) Slide, dan 3) Film Strip.

Asnawir dan Utsman (2002 : 79), media audio berkaitan dengan indera pendengar, dimana pesan yang disampaikan dituangkan dalam lambang-lambang auditif, baik verbal (ke dalam kata-kata atau bahasa lisan) maupun non verbal. Lebih lanjut Asnawir menjelaskan media yang dapat dikelompokkan dalam media audio, antara lain : 1) radio, 2) pita rekam magnetic, dan 3) laboratorium bahasa.

Asnawir dan Utsman (2002 : 93), media audio visual adalah media audio visual gerak yaitu dapat berupa 1) film bersuara atau gambar hidup atau 2) Televisi. Dua media audio visual tersebut merupakan alat audio visual lengkap, sedangkan slide yang ditambahkan suara bukan alat audio visual lengkap, karena suara dan rupa berada terpisah, oleh karena itu slide termasuk media visual saja atau media visual plus suara.

\section{METODOLOGI PENELITIAN}

Penelitian ini dilaksanakan di SMP Negeri 1 Ciledug Tahun Ajaran 2013-2014 yang beralamat di Jalan Merdeka Utara No. 130 Kec. Ciledug Kab. Cirebon dan yang menjadi sasarannya yaitu siswa kelas VIII.

Metode penelitian yang digunakan adalah metode penelitian dan pengembangan (Research and Development / R\&D). Menurut Sugiyono, Research and Development adalah metode penelitian yang digunakan untuk menghasilkan produk tertentu, dan menguji keefektifan produk tersebut. Model ADDIE adalah salah satu model desain sistem pembelajaran yang memperlihatkan tahapan-tahapan dasar desain sistem pembelajaran yang sederhana dan mudah dipelajari. Model ADDIE terdiri dari lima fase atau tahap utama, yaitu $(\boldsymbol{A})$ nalysis, (D)esain, (D)evelopment, (I)mplementation, dan (E)valuation. Kelima tahap dalam model ADDIE perlu dilakukan secara sistemik dan sistematik. Model desain system pembelajaran ADDIE dengan komponenkomponennya dapat digambarkan dalam diagram gambar dibawah ini (Pribadi, 2009 : 125).

Populasi dalam penelitian ini adalah seluruh siswa kelas VIII SMP Negeri 1 Ciledug yang terdiri dari 9 kelas. Teknik pengambilan sampel yang digunakan dalam penelitian ini yaitu cluster random sampling. Dari teknik tersebut sampel yang terpilih adalah kelas VIII I sebagai kelas eksperimen dan kelas VIII G sebagai kelas kontrol. 


\section{HASIL DAN PEMBAHASA}

\section{Analysis}

Kegiatan dalam langkah awal pengembangan yaitu dengan menganalisis masalah-masalah atau menganalisis kinerja dan kebutuhan yang ada di SMP N 1 Ciledug tentang bahan ajar yang digunakan. Ditempat penelitian, penggunaan bahan ajar non cetak berupa media microsoft powerpoint masih sangat jarang digunakan. Bilapun digunakan bahan ajar non cetak tersebut masih kurang memotivasi siswa untuk belajar karena media yang kurang kreatif, kurang kondusif, efektif dan efisien. Sehingga hasil belajarpun masih kurang dari yang diinginkan. Untuk itu, peneliti menelusuri masalah yang ada dan memenuhi segala apa yang dibutuhkan. Seperti peneliti harus mengetahui bagaimana karakteristik siswa yang dimiliki, pengetahuan dan keterampilan seperti apa yang telah dimiliki oleh siswa, melakukan telaah tentang bahan ajar apa yang kira-kira dapat memotivasi siswa sehingga hasil belajarnyapun meningkat, dan masalah-masalah lainnya. Peneliti memilih untuk mengembangkan bahan ajar berbasis audio visual dalam hal ini desainnya berbentuk microsoft powerpoint yang diaplikasikan dengan camtasia studio sehingga terbentuklah sebuah video.

\section{Desain}

Dalam pembuata desain meliputi pendahuluan, petunjuk, pengantar, materi, referensi dan profil. Contoh desain yang digunakan dapat dilihat melalui gambar di bawah ini

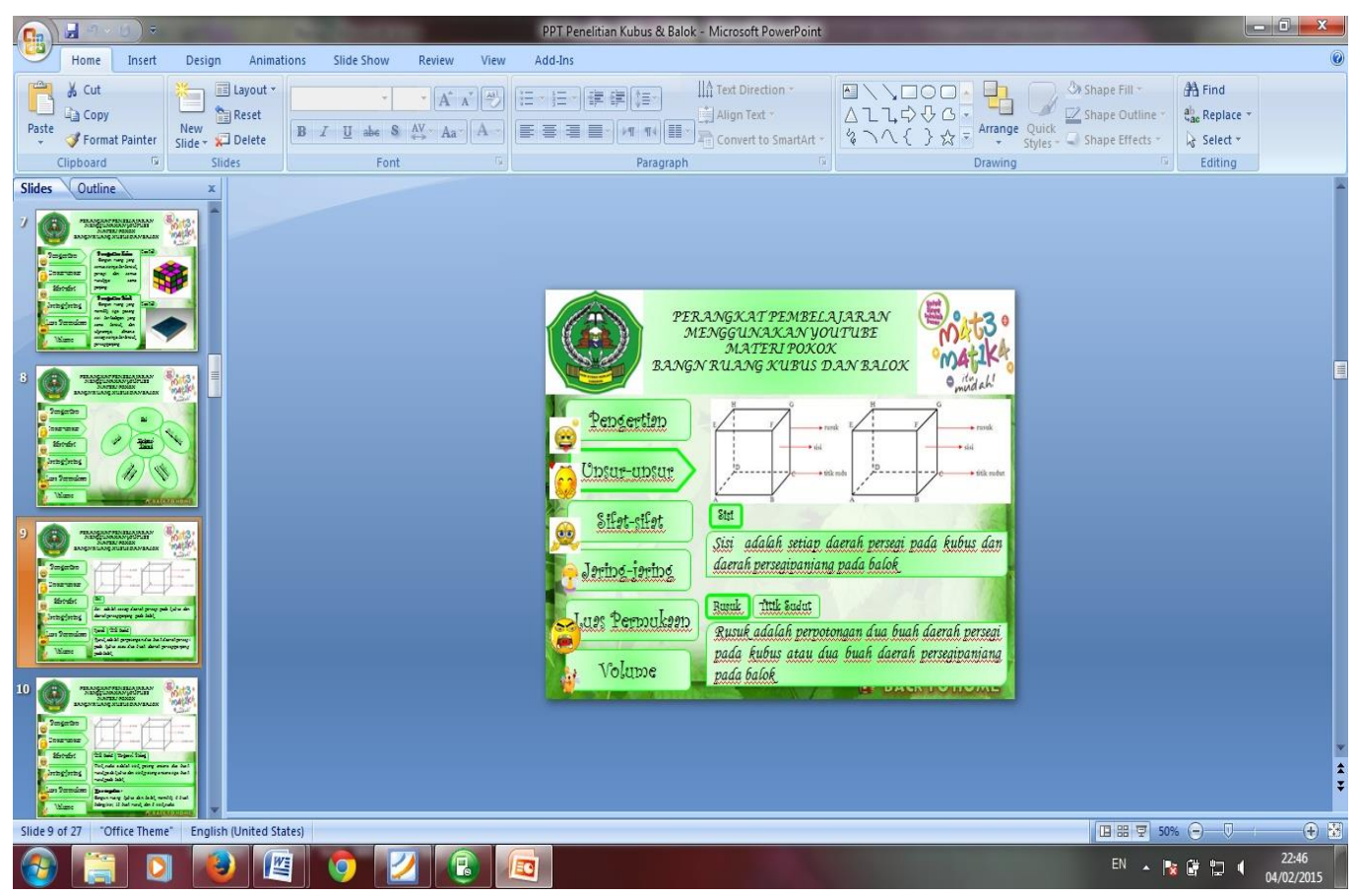

\section{Development}

Sebagai pengembangan bahan ajar peneliti memilih dua orang ahli materi dan dua orang ahli media untuk menilai media yang telah dibuat. Adapun keempat ahli yang berkenan menilai media tersebut adalah Guru Mata Pelajaran Matematika Kelas VIII SMPN 1 Ciledug yaitu Ibu Wahyuni S.Pd. sebagai ahli materi I dan dosen IAIN Syekh Nurjati Cirebon yaitu Bapak Saluky M.Kom. 
sebagai ahli materi II. Sedangkan untuk ahli media adalah dosen IAIN Syekh Nurjati Cirebon yaitu Bapak Saluky M.Kom. sebagai ahli media I dan Guru Mata Pelajaran Komputer SMPN 1 Ciledug yaitu Bapak Saeroji S.Pd. sebagai ahli media II.

\section{Implementation}

Kegiatan pada tahap ini yaitu dengan mengimplementasikan media yang telah diberikan kepada kelas eksperimen. Pada tahap ini, pengujian keefektifan bahan ajar berbasis audio visual dengan menggunakan nilai hasil pretest-postest antara kelas eksperimen dan kelas kontrol. Pengambilan hasil pretest-postest berdasarkan siswa yang
ISSN $2086-3918$

mengikuti kedua test tersebut. Selain itu juga disesuaikan jumlah siswa eksperimen dan kelas kontrol. Hal ini dilakukan untuk mencari nilai N-Gain. Dari data hasil pretest dan posttest kelas eksperimen dan kelas kontrol, peneliti menyetarakan menjadi 40 siswa kelas eksperimen dan 40 siswa kelas kontrol.

Setelah dilakukan penerapan bahan ajar yang kemudian didapatkan suatu data hasil belajar matematika siswa. Berikut ini merupakan hasil perolehan hasil belajar antara siswa yang menggunakan pengembangan bahan ajar dengan kelas yang konvensional.

Grafik 1

Hasil Belajar Kelas Eksperimen dan N-Gain

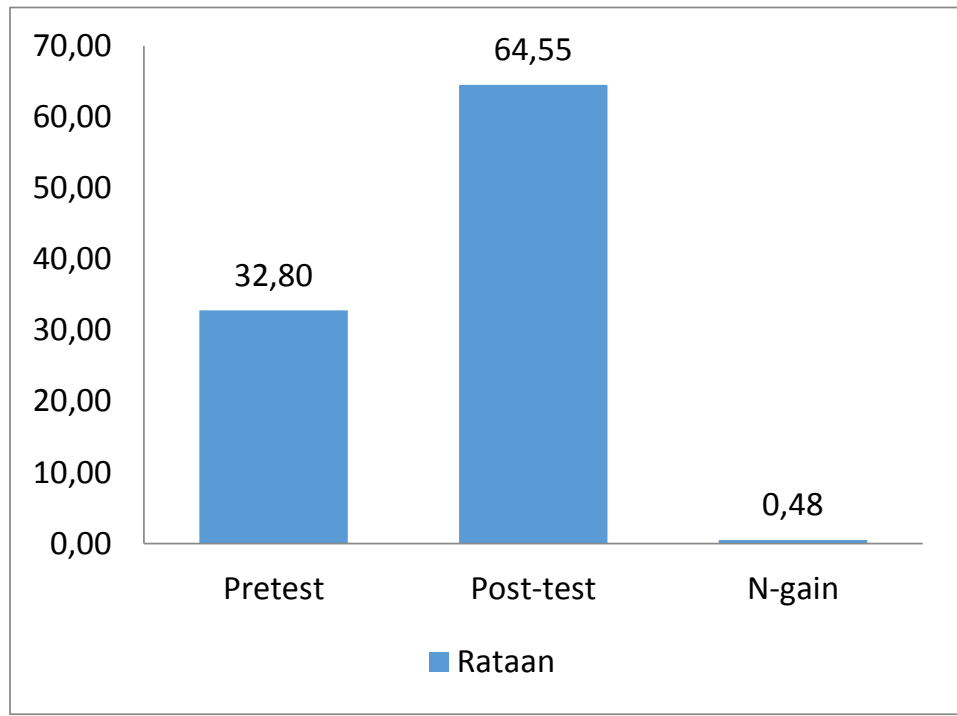

Berdasarkan grafik di atas diketahui bahwa nilai rata-rata pretes sebesar 32,80 dan ratarata postes sebesar 64,55. Sehingga mengalami peningkatan sebesar 0,48. 
Grafik 2

Hasil Belajar Kelas Kontrol dan N-gain

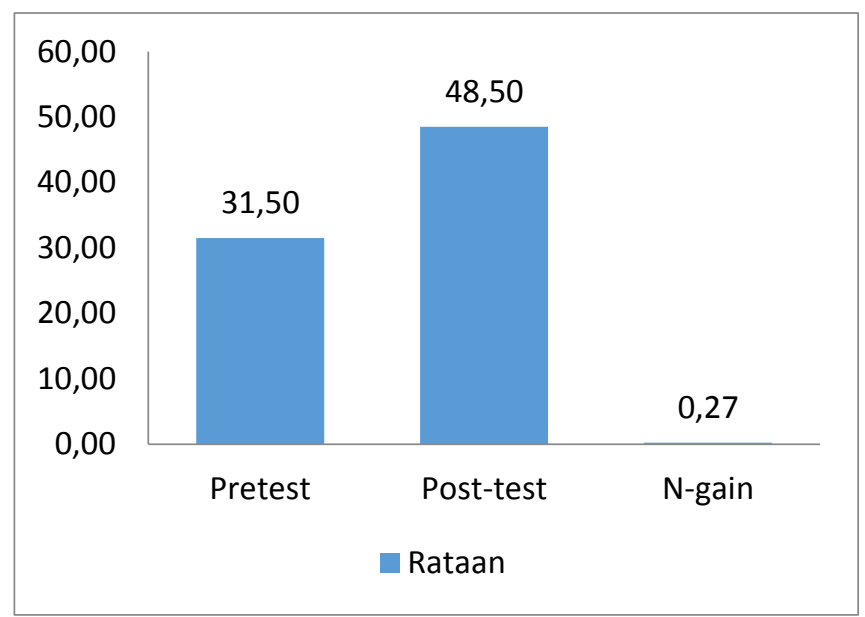

Berdasarkan grafik 2 di atas diketahui bahwa nilai rata-rata pretes sebesar 31,50 dan rata-rata postes sebesar 48,50, Sehingga mengalami peningkatan sebesar 0,27.
Data hasil belajar yang diperoleh kemdian dianalisis secara statistik parametrik, hasil uji normalitas dapat dilihat melalui tabel di bawah ini.

Tabel 1

Tests of Normality

\begin{tabular}{|c|c|c|c|c|c|c|c|}
\hline & \multirow[t]{2}{*}{ Data } & \multicolumn{3}{|c|}{ Kolmogorov-Smirnova } & \multicolumn{3}{|c|}{ Shapiro-Wilk } \\
\hline & & Statistic & $\mathrm{Df}$ & Sig. & Statistic & $\mathrm{df}$ & Sig. \\
\hline $\mathrm{N}-$ & $\begin{array}{l}\text { Kelas } \\
\text { Eksperimen }\end{array}$ & .134 & 40 & .067 & .919 & 40 & .007 \\
\hline & Kelas Kontrol & .264 & 40 & .000 & .872 & 40 & .000 \\
\hline
\end{tabular}

a. Lilliefors Significance Correction

Berdasarkan tabel di atas pada data $\mathrm{N}$-gain kelas eksperimen dan $\mathrm{N}$-gain kelas kontrol, dengan tingkat kepercayaan $\alpha=0,05$ diperoleh nilai signifikansi (Sig.) baik pada uji Shapiro Wilk (Sig. 0,007 dan 0,0000) dan Kolmogorov-Smirnov (0,067 dan 0,000) kesemuanya $<0,05$, artinya data berdistribusi secara tidak normal sehingga tes yang digunakan adalah Nonparametric Tests Two Independents Samples. Sedangkan dari perhitungan homogenitas diketahui bahwa nilai Sig. di atas 0,05 $(0,840>0,05)$ dengan demikian dapat disimpulkan data tersebut berdistribusi homogen
Tabel 3

Test Statistics ${ }^{a}$

\begin{tabular}{|l|l|}
\hline & N-gain \\
\hline Mann-Whitney U & 394.000 \\
Wilcoxon W & 1214.000 \\
Z & -3.917 \\
Asymp. Sig. (2-tailed) & .000 \\
\hline
\end{tabular}

a. Grouping Variable: Data 
Berdasar data di atas diperoleh nilai $Z_{\text {hitung }}>Z_{\text {tabel }}(-3,917>$-1,96) dan Asym. Sig (2-tailed) sebesar $0,000<0.05$, dengan demikian dapat disimpulkan terdapat perbedaan hasil belajar antara kelas eksperimen dan kelas kontrol pada N-gain, hal ini dapat di lihat pada rank kelas eksperimen 50,65 dan rank kelas kontrol sebesar 30,35, dengan demikian dapat disimpulkan bahwa hasil belajar kelas eksperimen lebih baik daripada kelas kontrol.

\section{Evaluation}

Langkah terakhir dari pengembangan ini adalah Evaluation. Sebenarnya evaluasi telah dilakukan pada tahap ketiga yaitu berupa evaluasi ahli untuk mengetahui kualitas media, pada tahap ini diperoleh besarnya respon siswa terhadap media yang dikembangkan.

\section{PEMBAHASAN}

Hasil penelitian yang telah dilakukan, akhirnya peneliti mendapatkan hasil dari perumusan masalah yang telah dirumuskan sebelumnya. Bahan ajar berbasis audio visual yang telah divalidasi oleh dua ahli media dan dua ahli materi pembelajaran. Ahli media yang melakukan penilaian bahan ajar berbasis audio visual ini adalah dosen IAIN Syekh Nurjati Cirebon Bapak Saluky, M.Kom. sebagai ahli media I dan guru mata pelajaran komputer kelas VIII SMP N 1 Ciledug itu sendiri yaitu Bapak Saeroji, S.Pd. sebagai ahli media II. Berdasarkan hasil validasi terhadap media yang diperoleh dari dua ahli media dan dua ahli materi, dari segi ahli materi diperoleh prosentase sebesar 90\% (Baik) untuk kualitas isi dan tujuan dan 84\% (Cukup) untuk kualitas pembelajaran. Sedangkan dari segi ahli media diperoleh prosentase sebesar 80\% (Cukup) untuk kualitas rekayasa perangkat lunak dan 85,7\% (Cukup) untuk kualitas desain pembelajaran dan 81,5\% (Cukup) untuk kualitas komunikasi visual. Sehingga secara keseluruhan hasil dari ahli materi menunjukkan prosentase $87 \%$ dengan kriteria Baik sedangkan hasil dari ahli media juga menunjukkan prosentase $82,4 \%$ dengan kriteria Cukup.

Berdasarkan hasil validasi dari ahli media dan materi pembelajaran tersebut, bahwa bahan ajar berbasis audio visual sudah layak digunakan meskipun ada sedikit revisi, komentar dan saran dari dosen pembimbing, ahli media dan ahli materi pembelajaran.

Tahap uji coba dilakukan secara 2 kali yaitu uji coba terbatas pada tahap implementasi dan uji coba luas pada tahap development. Dari uji coba terbatas diketahui kelemahan dan kekurangan bahan ajar berbasis audio visual yang dibuat, maka peneliti melakukan revisi yang kedua setelah melakukan uji coba terbatas. Pada uji coba ke-2 yaitu uji coba luas didapat beberapa hasil untuk melihat efektif atau tidaknya bahan ajar berbasis audio visual tersebut.

Pada pengujian keefektifan produk menggunakan perhitungan dari hasil analisis Uji Two Independent Samples diperoleh nilai $Z_{\text {hitung }}>Z_{\text {tabel }}(-3,917>-1,96)$ dan Asym. Sig (2-tailed) sebesar 0,000<0.05, 
dengan demikian dapat disimpulkan terdapat perbedaan hasil belajar antara kelas eksperimen dan kelas kontrol pada Ngain, hal ini dapat di lihat pada rank kelas eksperimen 50,65 dan rank kelas kontrol sebesar 30,35, dengan demikian dapat disimpulkan bahwa hasil belajar kelas eksperimen lebih baik daripada kelas kontrol.

\section{KESIMPULAN}

1. Pengembangan bahan ajar ini menggunakan model ADDIE yang terdiri dari lima tahapan yaitu Analysis, Design, Development, Implementation, dan Evaluation. Pada tahap Analysis dilakukan analisis silabus. Pada tahap design dibuat program yang akan dibangun dan mengumpulkan semua bahan yang dibutuhkan serta menyiapkan software yang hendak digunakan yaitu microsoft powerpoint yang diaplikasikan dengan camtasia studi sehingga terbentuklah sebuah video. Tahap development diawali dengan membangun media hendak dikembangkan sesuai dengan desain yang telah dibuat. Setelah itu, dilakukan evaluasi terhadap media yang sedang dikembangkan oleh ahli media dan ahli materi. Tahap Implementation yaitu dengan mengimplementasikan media yang telah dibuat. Pada tahap ini juga dilakukan tes berupa pretest dan posttest kepada kelas eksperimen dan kontrol. Selain itu juga dilakukan penyebaran angket pada kelas eksperimen untuk mengetahui respon siswa terhadap media yang sedang dikembangkan. Tahap yang terakhir dari model ADDIE yaitu Evaluation. Pada tahap ini dilakukan analisis data dari hasil tes belajar siswa dan hasil angket yang telah disebarkan.

2. Uji keefektifan produk menggunakan perhitungan dari hasil analisis Uji Two Independent Sample diperoleh nilai $\mathrm{Z}_{\text {hitung }}>\mathrm{Z}_{\text {tabel }}$ (-3,917 > -1,96) dan Asym. Sig (2tailed) sebesar 0,000<0.05, dengan demikian dapat disimpulkan terdapat perbedaan hasil belajar antara kelas eksperimen dan kelas kontrol pada N-gain, hal ini dapat di lihat pada rank kelas eksperimen 50,65 dan rank kelas kontrol sebesar 30,35, dengan demikian dapat disimpulkan bahwa hasil belajar kelas eksperimen lebih baik daripada kelas kontrol.

3. Rata-rata respon siswa terhadap media yang dibuat mendapatkan skor sebesar 80\% dengan criteria Cukup untuk kualitas Rekayasa perangkat lunak, 85,7\% dengan kriteria Baik untuk kualitas Desain Pembelajaran dan 81,5\% dengan kriteria Cukup untuk kualitas Komunikasi Visual. Sehingga secara keseluruhan hasil dari ahli materi menunjukkan prosentase 87\% dengan kriteria Baik sedangkan hasil dari ahli media juga menunjukkan prosentase 82,4\% dengan kriteria Cukup. 
Berdasarkan hasil validasi dari ahli media dan materi pembelajaran tersebut, bahwa bahan ajar berbasis audio visual sudah layak digunakan meskipun ada sedikit revisi, komentar dan saran dari dosen pembimbing, ahli media dan ahli materi pembelajaran

\section{SARAN}

1. Saran Pemanfaatan

Penulis menyarankan agar bahan ajar berbasis audio visual yang telah dikembangkan ini perlu diujicobakan dalam kegiatan pembelajaran matematika materi bangun ruang kubus dan balok kelas VIII untuk mengetahui sejauh mana kelebihan dan kekurangan bahan ajar berbasis audio visual tersebut. Pada proses pembelajaran, bahan ajar berbasis audio visual dapat digunakan acuan guru sekaligus dapat dipakai oleh siswa sebagai tambahan sumber belajar

2. Pengembangan Bahan Ajar Berbasis Audio Visual Lebih Lanjut

Bahan ajar berbasis audio visual materi bangun ruang kubus dan balok dapat digunakan dan dikembangkan lebih lanjut dalam proses pembelajaran yang melibatkan guru dan siswa. Guru diharap lebih kreatif dalam membuat video tentang materi bangun ruang kubus dan balok, sedangkan siswa lebih aktif dalam belajar untuk mempengaruhi pengalaman belajar.

\section{DAFTAR PUSTAKA}

Arikunto, Suharsimi. (2006). Prosedur Penelitian Suatu Pendekatan Praktik. Cet. XIII. Jakarta : PT. Rineka Cipta

Arsyad, Azhar. (2003). Media Pembelajaran. Cet. IV. Jakarta : PT Raja Grafindo Persada.

Asnawir, H., \& Usman, M.B. (2002). Media Pembelajaran. Jakarta : Ciputat Pers.

Baskoro, E.P. (2008). Media Pembelajaran. Cirebon : ABW Print

Prastowo, Andi. (2011). Panduan Kreatif Membuat Bahan Ajar Inovatif. Jogjakarta : Diva press.

Pribadi, B.A. (2009). Model Desain Sistem Pembelajaran. Cet. I. Jakarta : PT. Dian Rakyat.

Riduwan. (2010). Dasar-dasar Statistika. Bandung : Alfabeta.

Sanjaya, Wina. (2009). Perencanaan dan Desain Sistem Pembelajaran. Jakarta : Kencana

Sofan, Amri., \& Lif, K.A. (2010). Kontruksi Pengembangan Pembelajaran. Jakarta : PT. Prestasi Pustaka

Sugiyono. (2007). Statistika Untuk Penelitian. Bandung : Alfabeta

Susilawan, Rudi. (2011). Media Pembelajaran. Bandung : Wacana Prima 